\title{
Dormitory High School Evaluation with Army System at Magelang City
}

\author{
(at Taruna Nusantara Senior High School)
}

\author{
Tina Rosa* \\ Magister Business Administration \\ Respati Indonesia University \\ Indonesia \\ *tinarosa@urindo.ac.id
}

\author{
Radhita Anggoro Setiawan \\ Magister Business Administration \\ Universitas Respati Indonesia \\ Indonesia \\ raditaanggoro@ymail.com
}

\begin{abstract}
The idea of making Taruna Nusantara High School was sparked by the Minister of Defense and Security General LB Moerdani on May 20, 1985 at the Great Pavilion of Taman Siswa Yogyakarta. He has a vision to build a school that educates the best people from all over Indonesia and produces graduates who can continue the aspirations of the proclamator. This idea was continued by signing a Memorandum of Understanding between the Indonesia Arm Force with and Taman Siswa, which was the first educational organization in Indonesia, the Foundation of Indonesia Arm Force. The purpose of this study is to determine the factors to determine the factors that influence the competitiveness of both external factors and internal factors and find out the right strategy to increase competitiveness based on the SWOT analysis approach and AHP data processing tools. Data collection techniques were obtained by interview, observation and documentation. The Results of this study are based on those conducted by expert Respondents on the factors that influence in increasing competitiveness in the Taruna Archipelago High School in Magelang. External Factors (Competitions from similar schools, students who fail selection at TN High School Gaining the trust of parents of students and the wider community for the next career path, the existence of student sanctions). The right strategy and is used based on SWOT Analysis from the results of interviews with the expert team is to choose the strategy of Strength and Opportunity in terms of the application of quality and service in educational institutions (both in terms of Sarpras and HR).
\end{abstract}

Keywords—strategy analysis, SWOT

\section{INTRODUCTION}

Professional education institution both state and private compete in order to supply the prime service for creating the best graduation. Quality or qualification of education today become the attention by the decision makers in education sector. The meaning of decision maker is is government, related affairs, teacher, parent of student and student its self. Like a product, 1 the institution of education, in this matter is the school, have the consumer who always consider quality or qualification of school that will be chosen by them.

The main consumers in the world of education / school are the students themselves. Consumers will certainly choose products of the highest quality or quality. Likewise with prospective students, of course they will choose a school with the best quality as well. Therefore, schools are competing to show their quality and maintain the quality that has been formed. Development of higher quality education, among others, through the development and improvement of curriculum and evaluation systems, improvement of educational facilities, development and procurement of teaching materials, training of teachers and educators, and management development.

There are two factors that make the effort of revision of quality of education qualification when in this time is not success yet. Firstly, During this time the strategy of education development have a input oriented characteristic. That strategy tend to assumption whereas if all of inputs of education that have been fulfilled such as the supplying of books (material of teaching and other study equipment, Providing educational facilities, training teachers and other educational personnel, educational institutions can automatically produce quality outputs. This is not fully functional, the proof that what happens is only the emergence of economic and industrial institutions.

The appearing of new education institutions, in one side is the positive signal about high attention of government or society to the education sector but in other side is he competition inter education institution is more attractive. By this considering, marketing for educational institutions is absolutely necessary. Higher education institutions or schools as educational service providers need to learn and have initiatives to increase customer satisfaction (stakeholders), because education is a circular process that affects each other and is sustainable. Therefore, a marketing strategy for educational services is needed to win competitions between 
educational institutions, as well as to increase the acceleration of quality improvement and management professionalism of educational institutions, especially in SMA Taruna Nusantara Magelang. SMA Taruna Nusantara (also known as Tarnus or $\mathrm{TN}$ ) is a boarding high school located in Magelang Regency, Central Java, Indonesia.

\section{A. The Formulation of Problem}

Some ractor that support for analysis of strategy in competitiveness, namely :

- What factors fluence competitiveness, both external and internal factors in SMA Taruna Nusantara

- How about the the strategy of SMA Taruna Nusantara to increase competitiveness?

- What is the most he most appropriate to improve the competitiveness of SMA Taruna Nusantara based on the SWOT analysis approach and AHP data processing tools?

\section{B. The Purpose of Research}

Base on the problem which is any in this purpose of this research to be achieved by conducting this research are :

- To determine the factors that influence in increasing the competitiveness of both external and internal factors.

- To find out the strategy analysis at Taruna Nusantara Senior High School in increasing competitiveness.

- To find out the right strategy in increasing competitiveness based on the SWOT analysis approach and AHP data processing tools.

\section{LITERATURE STUDY}

\section{A. Strategy}

According to Ireland, Hoskisson, and Hitt [1] strategy is a tool of integration and coordination of commitments and actions designed to exploit core competencies and gain competitive advantage.

In particular, the strategy is the placement of the agency's mission, the setting of organizational goals by keeping in mind the external and the internal, the formulation of policies and certain ways to achieve goals and ensure their proper implementation, so that the main goals and objectives of the organization will be achieved [2]

From the explanation above, it can be concluded that strategy is planning and management using the resources of nations to achieve goals or careful planning regarding activities to achieve specific goals by showing operational tactics.

\section{B. Strategy Base on SWOT Analysis}

SWOT From the explanation above, it can be concluded that strategy is planning and management using the resources of nations to achieve goals or careful planning regarding activities to achieve specific goals by showing operational tactics.

\section{The Purpose and Functional of SWOT Analysis}

Erwin Suryatama [3] states that the purpose of a SWOT analysis is to help develop full awareness of all factors that can influence strategic planning and decision making, goals that can be applied to almost all aspects of the industry. SWOT is intended primarily for assessment techniques. Meanwhile, the benefits obtained from a SWOT analysis are as follows:

- As a guide for schools to formulate various strategic policies related to plans and implementation in the future. With this analysis, it is hoped that the company will be able to choose the best policies and plans for future business development.

- Become a form of material for evaluating strategic policies and planning systems of a school. SWOT analysis will help companies in thinking about various policy evaluation efforts that are considered detrimental and which ones are profitable.

- Providing information about the condition of the company, then through the existing information it will serve as a guide for school owners and policy makers to carry out various new policies as a solution to the results of the existing analysis.

- Provide challenges for new ideas for school management. The existence of various problems such as weaknesses, opportunities and small strengths or threats from outside parties that encourage school management to find new policy ideas.

\section{Method of Research}

The research was carried out at Taruna Nusantara Magelang Senior High School and at the Taman Taruna Nusantara Educational Institute (LPTTN) Jakarta. The determination of the sample in qualitative research is carried out when the researcher begins to enter the field and during the research. The subjects of this study were the highest managers in the SMA Taruna Nusantara and LPTTN who were the main informants. Subject selection was carried out by selecting samples from several teachers / pamong, LPTTN managers, school principals and deputy principals so that the research results were more representative. 


\section{A. Technique of Data Collecting}

The method used in this research is conducting interviews, observation, and documentation.

\section{RESULTS OF RESEARCH AND DISCUSSION}

\section{A. Analysis of Environment Factor}

The first stage is to conduct a study of internal and external factors in order to find the best alternative strategy to increase competitiveness in SMA Taruna Nusantara. Identification of factors related to strategies to improve competitiveness in SMA Taruna Nusantara is carried out by studying various literatures, documents and direct interviews with various parties (sources) who are believed to know (expert) the problem in detail.

\section{B. Analysis of Internal Environment}

Analysis of the company's internal environment is very important in knowing the suitability of the educational institution's strategy with the resources owned by the educational institution, in this case the school. By analyzing the internal environment, it can be seen the strengths and weaknesses of the school.

\section{Analysis of External Environment}

External environmental analysis aims to determine threats and opportunities for schools. The external environment of the school is factors beyond the control of educational institutions but has an indirect effect on schools, such as affecting the choice of direction and school actions.

TABLE I. SWOT ANALYSIS FOR TARUNA NuSANTARA SENIOR High SCHOOL

\begin{tabular}{|c|c|c|c|}
\hline Internal Strategic Factors & Grade & Rating & $\begin{array}{c}\text { Grade X } \\
\text { Rating }\end{array}$ \\
\hline $\begin{array}{l}\text { Strengts }(\mathrm{S}) \text { : } \\
\text { - Have qualufy teacher } \\
\text { - To use different curriculum than } \\
\text { other school } \\
\text { - The strong graduation network } \\
\text { - Qualify Graduation } \\
\text { - Schoole which is only one of } \\
\text { boarding school di Magelang } \\
\text { - strategic calm and feasible } \\
\text { environment } \\
\text { - have complete infrastructure }\end{array}$ & $\begin{array}{l}0,10 \\
0,10 \\
0,10 \\
0,09 \\
0,10 \\
0,09 \\
0,10\end{array}$ & $\begin{array}{l}4 \\
4 \\
4 \\
3 \\
4 \\
3 \\
4\end{array}$ & $\begin{array}{l}0,40 \\
0,40 \\
0,40 \\
0,27 \\
0,40 \\
0,27 \\
0,40\end{array}$ \\
\hline Subtotal (S) & 0,68 & & 2,54 \\
\hline $\begin{array}{l}\text { Weakness (W): } \\
\text { - Competency from same kind of } \\
\text { school } \\
\text { - The decreasing of total of } \\
\text { graduation of police academy and } \\
\text { military academy } \\
\text { - Non effective promotion } \\
\text { - The limitation of student } \\
\text { enrollment }\end{array}$ & $\begin{array}{l}\mathbf{0 , 0 4} \\
\mathbf{0 , 1 0} \\
\\
\mathbf{0 , 0 9} \\
\mathbf{0 , 0 9}\end{array}$ & $\begin{array}{l}2 \\
4 \\
3 \\
3\end{array}$ & $\begin{array}{l}\mathbf{0 , 0 8} \\
\mathbf{0 , 4 0} \\
\\
\mathbf{0 , 2 7} \\
\mathbf{0 , 2 7}\end{array}$ \\
\hline Subtotal $(\mathbf{W})$ & $\mathbf{0 , 3 2}$ & & 1,02 \\
\hline Total & 1,00 & & $\mathbf{3 , 5 6}$ \\
\hline
\end{tabular}

TABLE II. EFAS SMA TARUNA NUSANTARA

\begin{tabular}{|c|c|c|c|}
\hline External Strategic Factors & Grade & Rating & $\begin{array}{c}\text { Grade X } \\
\text { Rating }\end{array}$ \\
\hline $\begin{array}{l}\text { Oportunities }(\mathrm{O}) \text { : } \\
\text { - More many the candidate of } \\
\text { student for the schools in Taruna } \\
\text { Nusantara High School } \\
\text { - There is career level } \\
\text { - To supply the best graduation } \\
\text { - To grow nationalism spirit } \\
\text { - To get the awareness or appretiation } \\
\text { from around institution } \\
\text { - There is an opportunity for continue } \\
\text { the education to the abroad }\end{array}$ & $\begin{array}{l}\mathbf{0 , 1 0} \\
\\
\mathbf{0 , 1 0} \\
\mathbf{0 , 1 4} \\
\mathbf{0 , 1 4} \\
\mathbf{0 , 1 0} \\
\\
0,14\end{array}$ & $\begin{array}{l}3 \\
3 \\
4 \\
4 \\
3 \\
4\end{array}$ & $\begin{array}{r}\mathbf{0 , 3 0} \\
0,30 \\
0,56 \\
0,56 \\
0,30 \\
0,56\end{array}$ \\
\hline Subtotal (O) & $\mathbf{0 , 7 2}$ & & 2,58 \\
\hline $\begin{array}{l}\text { Threat (T): } \\
\text { - Competency from same kind of } \\
\text { school } \\
\text { - The student who failures in } \\
\text { selection } \\
\text { - There is sanction of student } \\
\text { Adanya sanksi Siswa }\end{array}$ & $\begin{array}{l}\mathbf{0 , 1 0} \\
\mathbf{0 , 0 8} \\
\mathbf{0 , 1 0}\end{array}$ & $\begin{array}{l}3 \\
2 \\
3\end{array}$ & $\begin{array}{l}\mathbf{0 , 3 0} \\
\mathbf{0 , 1 6} \\
\mathbf{0 , 3 0}\end{array}$ \\
\hline Subtotal (T) & $\mathbf{0 , 2 8}$ & & $\mathbf{0 , 7 6}$ \\
\hline Total & $\mathbf{1 , 0 0}$ & & 3,34 \\
\hline
\end{tabular}

Based on this analysis (table 1 and 2), it shows that competitiveness in Taruna Nusantara Senior High School Magelang can be determined by a combination of internal and external factors.

\section{CONCLUSION AND SUGGESTION}

Based on the results of the SWOT analysis and AHP analysis, the SO, WO, ST, and WT strategies are produced.

SO Strategy: Implementation of quality and service in educational institutions (both in terms of sarpras and human resources) in building competitiveness with other schools. WO strategy: Build and improve quality and service systems to gain and maintain trust and quality (parents of students, human resources and quality of students). Strategy (ST): Build and improve systems (HR, sarpras and partnerships) to obtain and maintain quality in order to have high competitiveness. Strategy (WT): Verified in terms of quality, service, selection results and sarpras in $\mathrm{TN}$ schools so as to increase competitiveness with other schools.

Based on research conducted on expert respondents in the factors that influence in increasing competitiveness in SMA Taruna Nusantara Magelang are as follows: Internal factors (Vision and Mission SMA Taruna Nusantara, National network, Strong Alumni network, Curriculum and HR) External factors (competition from similar schools, students who fail the selection to enter SMA TN, getting the trust of students' parents and the wider community for the next career path, Student sanctions). The right strategy and is used based on SWOT and AHP from the results of interviews with the expert team is to choose an SO strategy in terms of implementing quality and service in educational institutions (both in terms of sarpras and HR).

\section{REFERENCES}

[1] Hoskisson and Hitt, 2013 p. 4

[2] Anshori, 2014 pp. 18-20.

[3] E. Suryatama, 2014 